Supporting Information for:

\title{
Electrochemical Strategy for Eradicating Fluconazole-Tolerant Candida albicans using Implantable Titanium
}

\author{
Eloise Parry-Nweye ${ }^{1 \$}$, Nna-Emeka Onukwugha ${ }^{1 \$}$, Sricharani Rao Balmuri ${ }^{1}$, Jackie L. Shane ${ }^{1}$, Dongyeop \\ $\mathrm{Kim}^{2}$, Hyun Koo ${ }^{2}$, Tagbo H. R. Niepa ${ }^{1,3,4,5,6 *}$ \\ ${ }^{1}$ Department of Chemical and Petroleum Engineering, University of Pittsburgh, Pittsburgh, PA, USA \\ ${ }^{2}$ Biofilm Research Laboratory, Department of Orthodontics and Divisions of Pediatric Dentistry \& \\ Community Oral Health, School of Dental Medicine, University of Pennsylvania, Philadelphia, PA, USA \\ ${ }^{3}$ Department of Bioengineering, ${ }^{4}$ Department of Civil and Environmental Engineering, ${ }^{5}$ Department of \\ Mechanical Engineering and Materials Science, ${ }^{6}$ Center for Medicine and the Microbiome, University of \\ Pittsburgh, Pittsburgh, PA, USA
}

\$equal contribution

${ }^{*}$ Corresponding author: tniepa@pitt.edu 


\section{Thermal transport across the electrochemical cell}

The COMSOL Multiphysics simulation was performed to evaluate the heat generation from the electrodes over the course of the treatment. The heat transfer module was used in the simulation, and the initial temperature was set for $21^{\circ} \mathrm{C}$ for the electrodes. The simulation of the thermal transport in the electrochemical cells demonstrates that the $C$. albicans cells do not experience significant change in thermal energy (Fig. S1a). To verify the simulation analysis, a thermometer was introduced in the electrochemical cell to measure the average temperature changes as a function of time for the treatment with $4 \mathrm{~V}$. The experimental measurements and modeling of energy transport indicate that the temperature within the cell remains constant within $+/-0.2^{\circ} \mathrm{C}$ (Fig. S1b).

a)

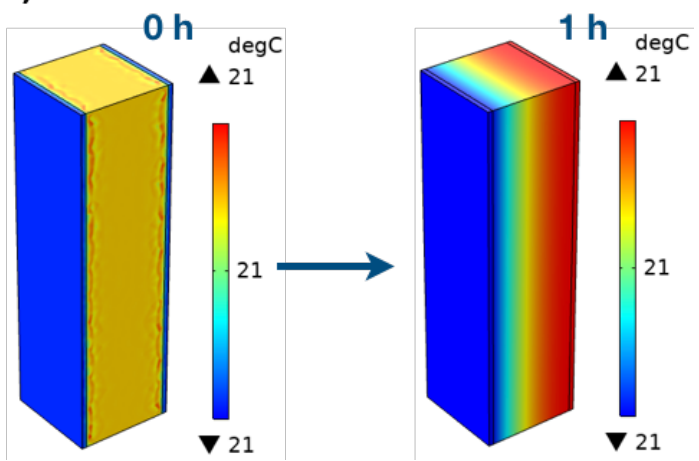

b)

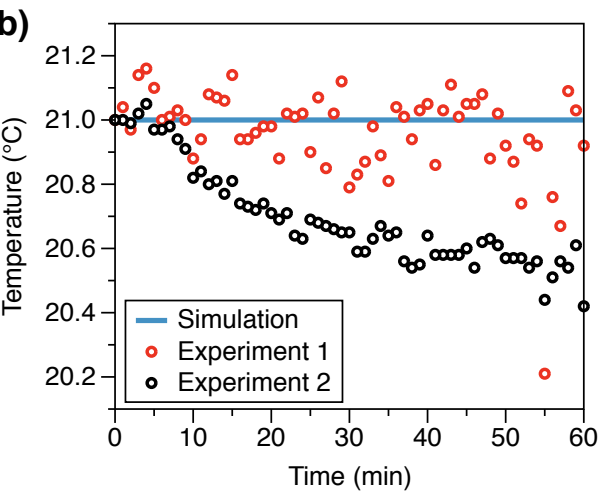

Fig. S1. COMSOL simulation of the thermal transport within the electrochemical cells generated $70 \mu \mathrm{A} / \mathrm{cm}^{2}$ DC using Ti electrodes $(3 \mathrm{~cm} \times 3 \mathrm{~cm} \times 0.1 \mathrm{~cm})$ in an electrochemical cell. a) The initial temperature was set to room temperature $\left(21^{\circ} \mathrm{C}\right)$ and remained steady after $1 \mathrm{~h}$ of the electrochemical treatment. b) The temperature was measured experimentally and plotted against the simulation data.

\section{Voltage profile across the electrochemical cell.}

COMSOL Multiphysics simulations were performed to investigate the voltage profile across the electrochemical cells during the treatments and assess corresponding electrical conductivities. The electrochemical cell was constructed in the exact geometry as our experimental system. Titanium [solid, alpha] was used as the material for the counter and the working electrodes. Additionally, liquid $\mathrm{NaCl}$ material was selected as the medium, and the density was adjusted to $1085 \mathrm{~kg} / \mathrm{m}^{3}$ to represent the solution 
of $154 \mathrm{mM} \mathrm{NaCl}$ used in the experiments. A blank material with properties similar to biological material such as the spleen was used to represent the microbial suspension in $154 \mathrm{mM} \mathrm{NaCl}$ solution. The current densities comprised between 17.5 and $70 \mu \mathrm{A} / \mathrm{cm}^{2}$ DC were applied through one terminal (electrode 1), while the second electrode served as a ground. Furthermore, a physics-controlled mesh was applied, and a time-dependent study was performed to record the voltage profile in the electrochemical cell.

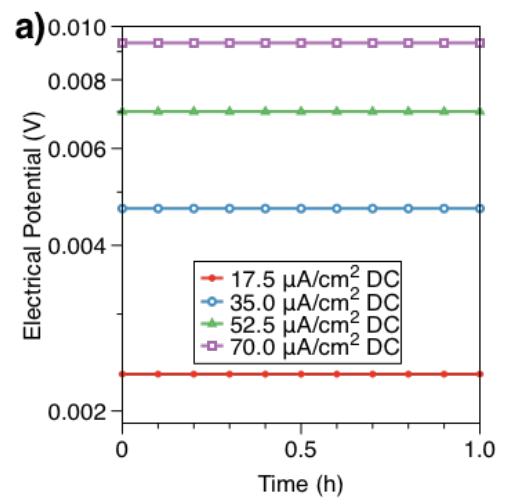

c)
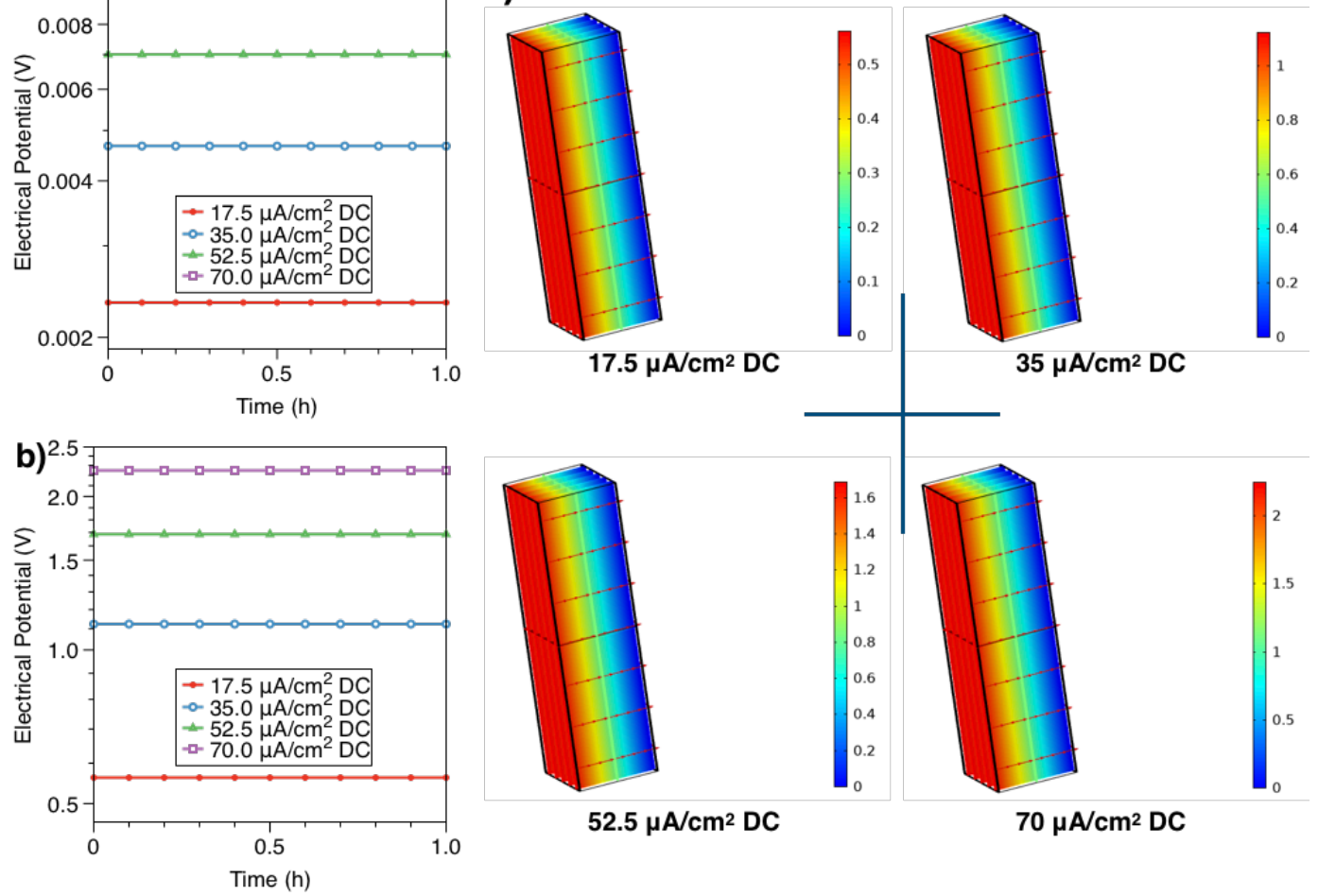

$70 \mu \mathrm{A} / \mathrm{cm}^{2} \mathrm{DC}$

Fig. S2. Profile of the electrical potentials of the medium develop using COMSOL simulation for a medium similar to a) $154 \mathrm{mM} \mathrm{NaCl}$ solution or b) suspension of $C$. albicans with an electrical conductivity of $6 \mathrm{mS} / \mathrm{m}$. c) The profile of the voltage across the cells shows that a potential gradient is established and that cells might not experience similar voltage. The effects of the treatments on the cells may be attributed to the current of the electrochemical species.

The voltage profile in the electrochemical cell suggests that biological cells experienced a potential gradient throughout the treatment (Fig. S2). In the absence of biological cells, a potential difference in the $\mathrm{mV}$ range was established across the electrochemical cell (Fig. S2a). However, the presence of the cells leads to high potential being recorded in the potentiodynamic experiments (Fig. S2b), indicating that the impedance 
of the medium affected charge transport across the medium. Unlike the actual experiment with $70 \mu \mathrm{A} / \mathrm{cm}^{2}$ DC, the potential profile reached its steady state almost immediately when the current density was applied during the simulation. Therefore, the fluctuation in the potentials recorded under the experimental conditions of $70 \mu \mathrm{A} / \mathrm{cm}^{2} \mathrm{DC}$ might suggest a dynamic change in the impedance of the media due to cell activity, such as the release of extracellular materials as observed in Fig. 3.

The electrical conductivity of the biological cells was varied from $1 \mathrm{mS} / \mathrm{m}$ to $100 \mathrm{mS} / \mathrm{m}$, and the electrical potential was measured for an applied current density of $70 \mu \mathrm{A} / \mathrm{cm}^{2} \mathrm{DC}$ (Fig. S3a) yo evaluate how changes in the medium conductivity might affect the electrical potential. Additionally, the data were fitted to correlate the changes in the medium conductivity with the electrical potentials (Fig. S3b). According to our results, the electrical conductivity of the medium decreases from 10 to $2 \mathrm{mS} / \mathrm{m}$ in $1 \mathrm{~h}$ of the treatment with 70 $\mu \mathrm{A} / \mathrm{cm}^{2} \mathrm{DC}$ (Fig. S3c).
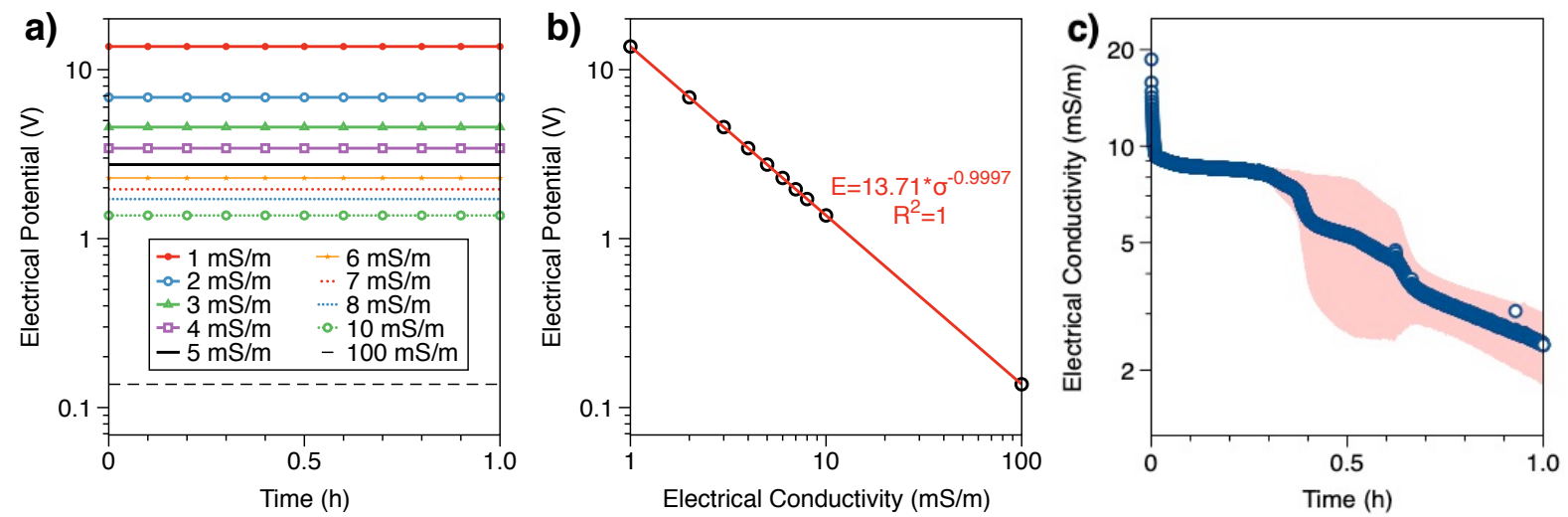

Fig. S3. Correlation between the electrical conductivity of the medium and potential recorded with $70 \mathrm{uA} / \mathrm{cm}^{2}$ DC. a) COMSOL simulation was used to evaluate the change in the electrical potential as a function of the electrical conductivity. In accordance with Ohm's law, for a constant current of $70 \mathrm{uA} / \mathrm{cm}^{2} \mathrm{DC}$, the electrical potential increases with the rise of the electrical conductivity. b) The electrical potential was plotted as a function of the electrical conductivity. The power fit of the curve established the relationship between the two electrical properties. c) The fit for the curve of the electrical potential vs. conductivity was used to determine the change in the electrical conductivity of the medium based on the experimental data illustrated in Fig. 3b. The conductivity decreased as a function of time, implying an increased resistivity of the medium. The standard deviation has been represented in pink. 


\section{Electrochemically-induced changes on Ti electrodes}

The corrosion behavior of Ti was investigated under our electrochemical conditions. First, a polarization curve was recorded to evaluate changes occurring at the electrodes for electrochemical potentials ranging from $-3 \mathrm{~V}$ to $4 \mathrm{~V}$ (Fig. S4a). Furthermore, active corrosion was recorded at a negative potential, which is followed by the passivation of the electrode as the potential rises from -1 to $1 \mathrm{~V}$. A breakdown of the oxide layer occurred repetitively between $1 \mathrm{~V}$ and $2 \mathrm{~V}$, which was followed by a re-passivation of the electrode (Fig. S4a). The SEM analyses were performed to investigate the change in the surface properties of the Ti electrode due to the potentiodynamic corrosion in reference to the untreated Ti material (Fig. S4b). As shown in Fig. S4c and d, pitting corrosion and deposition of Ti particles on the electrodes occurred during the polarization from $-3 \mathrm{~V}$ to $4 \mathrm{~V}$. This may suggest that the generation of negative potential might compromise the surface properties of the electrodes.
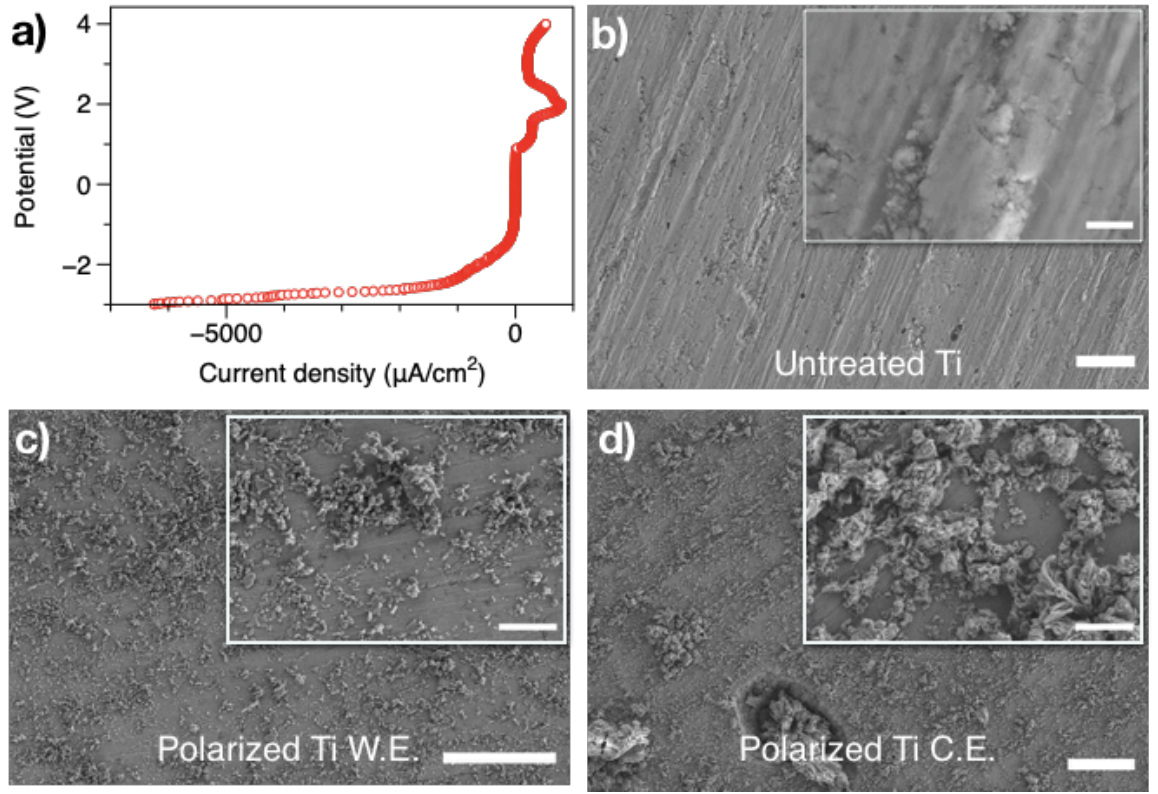

Fig. S4. a) Anodic and cathodic polarization curve from $\mathrm{Ti}$ in $154 \mathrm{mM} \mathrm{NaCl}$ solution. A voltage ranging between -3 and $4 \mathrm{~V}$ was generated at a scanning rate of $10 \mathrm{mV} / \mathrm{s}$ to evaluate the corrosion behavior of the Titanium electrodes. b-d) Effects of the potential on the working electrode (W.E.) and counter electrode (C.E.) Ti electrodes. Unlike the untreated Ti materials, which presents a smooth surface (Scale Bar: $10 \mu \mathrm{m}$ and $1 \mu \mathrm{m}$ for magnification images, respectively). (b) Ti electrodes used to generate a potential comprised between -3 and $-1 \mathrm{~V}$ experienced active corrosion. Ti microparticles were deposited on the electrodes (c, 
d), and pitting corrosion was observed on the polarized Ti cathode (d). (Scale Bar: $50 \mu \mathrm{m}$ and $5 \mu \mathrm{m}$ for magnification images, respectively.)

The potential of $2 \mathrm{~V}$ and $4 \mathrm{~V}$ were generated with the Ti electrodes in $154 \mathrm{mM} \mathrm{NaCl}$ solution for $1 \mathrm{~h}$ in order to evaluate the corrosion behavior of the Ti electrodes after the electrochemical treatments of $C$. albicans. Subsequently, the SEM analyses were performed to evaluate the integrity of the electrode materials after potential generation. In comparison to the untreated electrode (Fig. S4b), no significant corrosion was observed on the electrodes used for both the treatments with $2 \mathrm{~V}$ (Fig. S5a,b) and $4 \mathrm{~V}$ (Fig. S5c,d). In these experiments, anodic potentials were generated with the Ti electrodes. Besides the accumulation of salt crystals on the anode for the $4 \mathrm{~V}$ treatment, the electrodes remained intact.
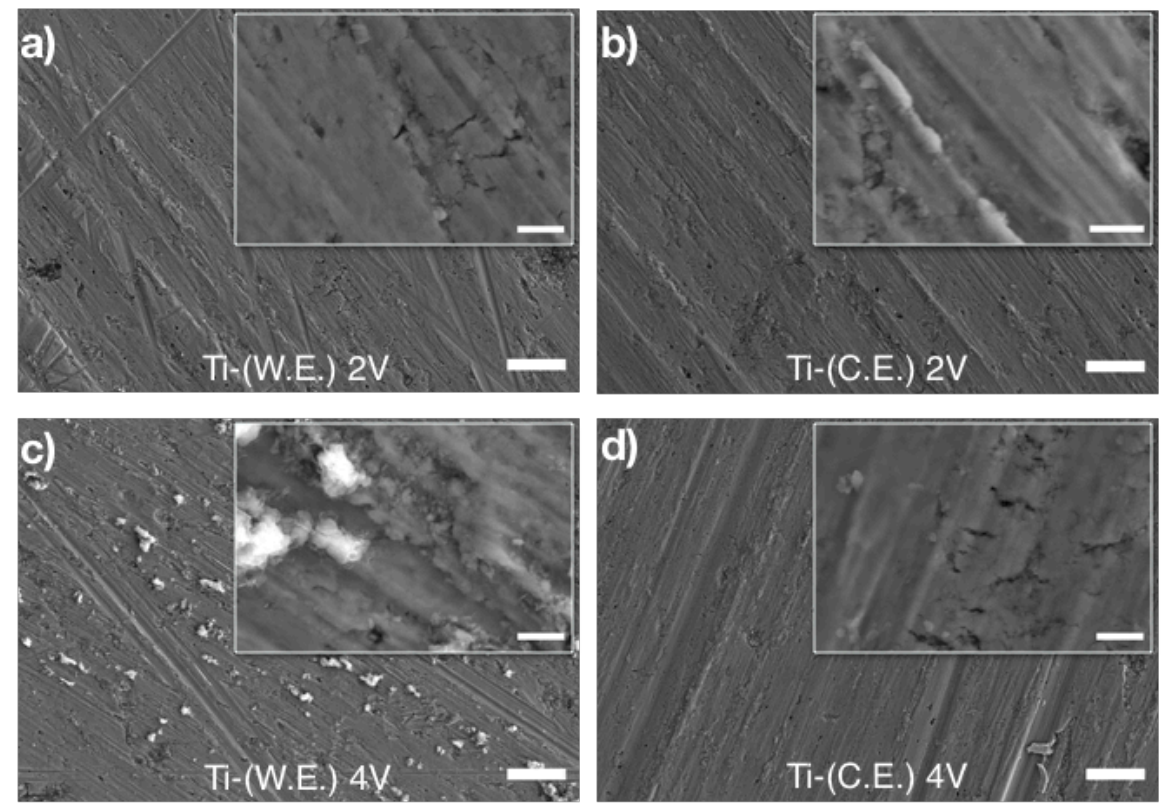

Fig. S5. Effects of the potential on working and counter Ti electrodes. The electrochemical treatment of a sterile solution of $154 \mathrm{mM} \mathrm{NaCl}$ was performed. Potentials of $2 \mathrm{~V}(\mathbf{a}, \mathbf{b})$ and $4 \mathrm{~V}(\mathbf{c}, \mathbf{d})$ were generated to evaluate the corrosion behaviors of the Ti electrodes in our ECT conditions. Additionally, no pitting corrosion was recorded on the a) working electrode (W.E.) or b) counter electrode (C.E.) after the treatment with 2 V. Similarly, the treatment with $4 \mathrm{~V}$ did not lead to any corrosion of the $\mathrm{c}$ ) anode and d) cathode. (Scale Bar: $10 \mu \mathrm{m}$ and $1 \mu \mathrm{m}$ for magnification images, respectively.) 

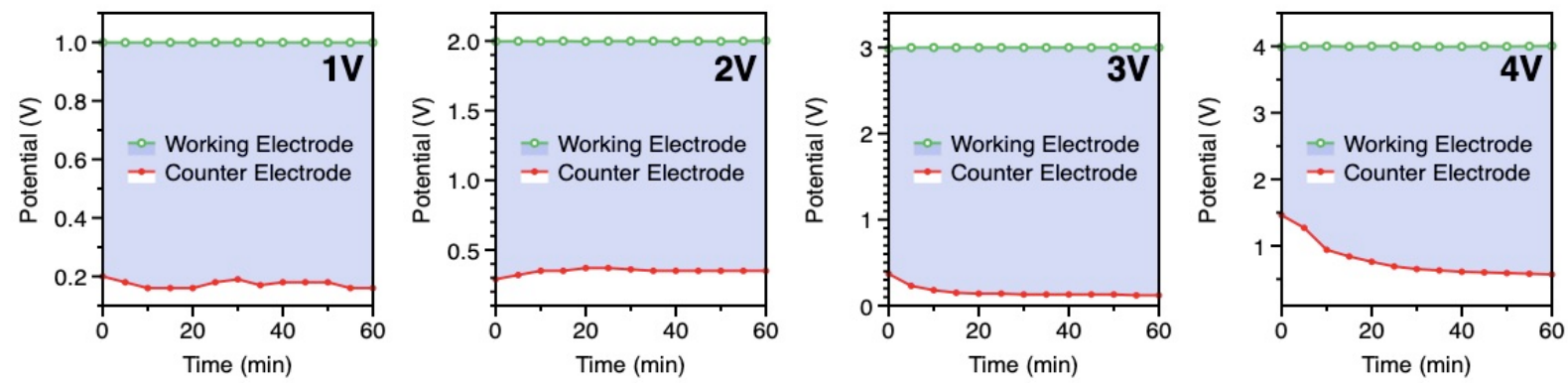

Fig. S6. Electrical potentials recorded at the working and the counter electrodes during the electrochemical treatments referred to at the $1,2,3,4 \mathrm{~V}$ conditions.

Possible redox reactions that might occur at the electrodes based of their standard potentials $\left(\mathrm{E}^{\circ}\right)$ include the following:

$$
\begin{array}{ll}
\mathrm{Ti}^{3+}+\mathrm{e}^{-} \rightarrow \mathrm{Ti}^{2+} & \mathrm{E}^{\circ}=-2.3 \mathrm{~V}^{1} \\
\mathrm{Ti}^{3+}+3 \mathrm{e}^{-} \rightarrow \mathrm{Ti}(\mathrm{s}) & \mathrm{E}^{\circ}=-1.209 \mathrm{~V}^{1} \\
\mathrm{Ti}^{2+}+2 \mathrm{e}^{-} \rightarrow \mathrm{Ti}(\mathrm{s}) & \mathrm{E}^{\circ}=-1.63 \mathrm{~V}^{1} \\
\mathrm{TiO}_{2}^{2+}+4 \mathrm{H}^{+}+6 \mathrm{e}^{-} \rightarrow \mathrm{Ti}(\mathrm{s})+2 \mathrm{H}_{2} \mathrm{O} & \mathrm{E}^{\circ}=0.012 \mathrm{~V}^{1} \\
\mathrm{TiO}_{2}^{2+}+\mathrm{H}_{2} \mathrm{O}+2 \mathrm{e}^{-} \rightarrow \mathrm{HTiO}_{3}^{-}+\mathrm{H}^{+} & \mathrm{E}^{\circ}=1.3 \mathrm{~V}^{1} \\
\mathrm{TiO}_{2}^{2+}+2 \mathrm{H}^{+}+2 \mathrm{e}^{-} \rightarrow \mathrm{TiO}^{2+}+\mathrm{H}_{2} \mathrm{O} & \mathrm{E}^{\circ}=1.8 \mathrm{~V}^{1} \\
\mathrm{O}_{2}^{-}+\mathrm{H}_{2} \mathrm{O}+\mathrm{e}^{-} \rightarrow \mathrm{HO}_{2}^{-}+\mathrm{OH}^{-} & \mathrm{E}^{\circ}=0.20 \mathrm{~V}^{1} \\
\mathrm{O}_{2}^{-}+2 \mathrm{H}_{2} \mathrm{O}+3 \mathrm{e}^{-} \rightarrow 4 \mathrm{OH}^{-} & \mathrm{E}^{\circ}=0.645 \mathrm{~V}^{1} \\
\mathrm{HO}_{2}+\mathrm{O}_{2}+\mathrm{H}^{+}+\mathrm{e}^{-} \rightarrow \mathrm{O}_{3}+\mathrm{H}_{2} \mathrm{O} & \mathrm{E}^{\circ}=0.813 \mathrm{~V}^{1} \\
\mathrm{HO}_{2}+3 \mathrm{H}^{+}+3 \mathrm{e}^{-} \rightarrow 2 \mathrm{H}_{2} \mathrm{O} & \mathrm{E}^{\circ}=1.65 \mathrm{~V}^{1} \\
\mathrm{Cl}_{2}+\mathrm{H}_{2} \mathrm{O} \rightarrow \mathrm{Cl}^{-}+\mathrm{HOCl}^{+} \mathrm{H}^{+} & \mathrm{E}^{\circ}=1.138 \mathrm{~V}^{2} \\
\mathrm{HO}_{2}+\mathrm{H}^{+}+\mathrm{e}^{-} \rightarrow \mathrm{H}_{2} \mathrm{O}_{2} & \mathrm{E}^{\circ}=1.44 \mathrm{~V}^{1}
\end{array}
$$

Our electrochemical treatments cover a range of positive potential, $0.1-1.5 \mathrm{~V}$, at the counter electrode when positive potentials of $1,2,3$, and $4 \mathrm{~V}$ is applied at the working electrode (Fig. S6). Thus, we have not anticipated the galvanic corrosion of $\mathrm{Ti}$ as listed in equation (1)-(3). However, the oxidation of the oxide layer (4)-(6) coupled with the generation of reactive oxygen species through water hydrolysis (7)-(12) may occur. 


\section{Effects of hypochlorous acid on C. albicans cells}

C. albicans cells were exposed for $1 \mathrm{~h}$ to hypochlorous acid concentrations ranging between 0-200 mM $\mathrm{NaOCl}$ to determine if the chemical potentially generated during our electrochemical treatments could affect cell viability. Our results showed a dose-dependent activity of $\mathrm{NaOCl}$ against $C$. albicans cells. However, no viable $C$. albicans cells were found at concentration higher than $100 \mathrm{mM} \mathrm{NaOCl}$, corresponding to 7-log killing compared to the untreated control cells (Fig S7a, $p<0.0001$ ). The ability of $\mathrm{NaOCl}$ to reduce the growth potential of $C$. albicans was investigated as well. The cells were grown in UFTYE medium in the presence or the absence of $\mathrm{NaOCl}$ for $48 \mathrm{~h}$ to monitor growth inhibition by measuring the optical density of the culture using a plate reader (Cytation5, Biotek). The growth potentials of the cell at $\mathrm{NaOCl}$ concentrations comprised between 0-100 mM were comparable to the untreated control grown in UFTYE alone $\left(4300 \mathrm{OD}_{600}{ }^{*} \mathrm{~min}, p>0.5\right)$. However, significant growth inhibition was recorded at concentration higher than $150 \mathrm{mM} \mathrm{NaOCl}$, corresponding to a growth potential $1300 \mathrm{OD}_{600}{ }^{*} \min (p<0.0001)$ compared to the untreated control (Fig. S7b). Our results indicate that $\mathrm{OCl}^{-}$generation could have a major contribution in the killing mechanisms observed during the electrochemical treatment of $C$. albicans.
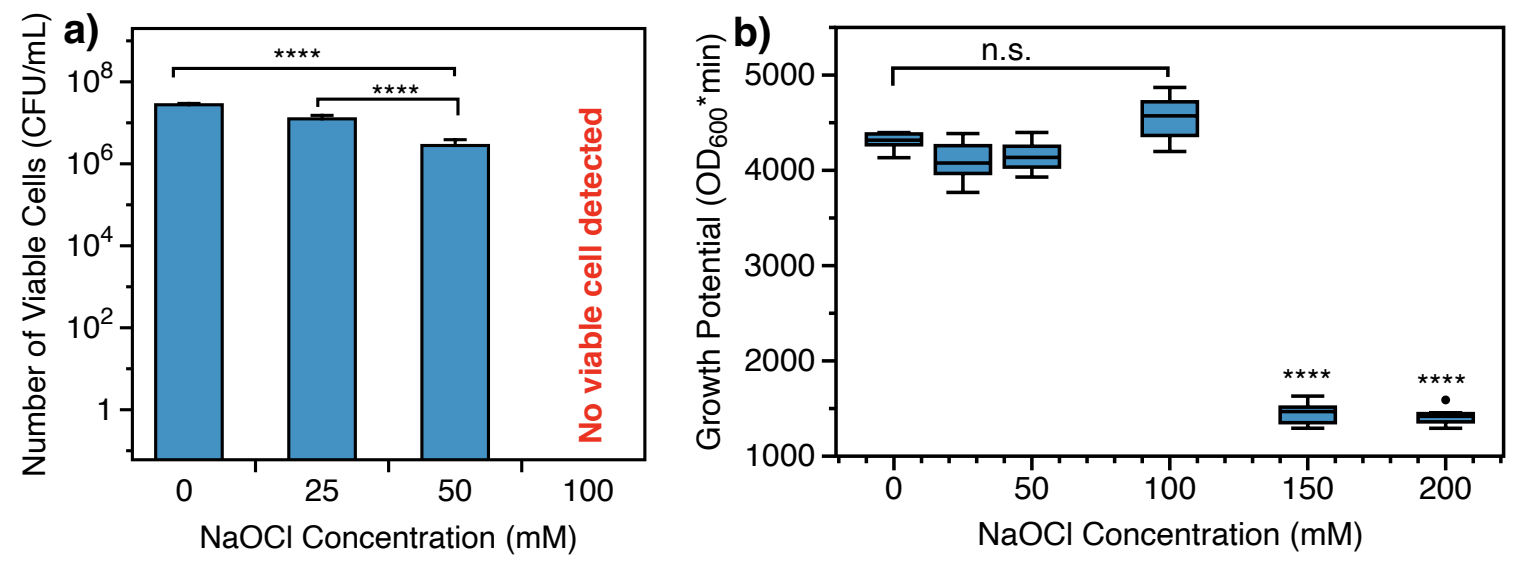

Fig. S7. a) Effects of $\mathrm{NaOCl}$ on planktonic $C$. albicans cells. No viable cell was found when the cells were treated with $100 \mathrm{mM} \mathrm{NaOCl}$. b) Growth inhibition effects of $\mathrm{NaOCl}$ on C. albicans cells. The growth potential of the cells was significantly reduced with $\mathrm{NaOCl}$ concentration higher than $150 \mathrm{mM}$. 


\section{Fluconazole treatment of $C$. albicans - Growth inhibition response}

To test the synergistic activity of the ECT and the drug, we have evaluated the effects of fluconazole (FLU, Diflucan, Sigma-Aldrich Chemical Group, St. Louis, and MO) on the growth of $C$. albicans. The objective was to determine a minimum concentration of FLU that would inhibit the growth of planktonic $C$. albicans in $200 \mu \mathrm{L}$ UFTYE medium using a microdilution technique. ${ }^{58}$ An initial mixture of $100 \mu \mathrm{g} / \mathrm{mL}$ FLU in UFTYE medium was serially diluted by two-fold across the plate to generate an array of UFTYE media with drug concentrations varying between $0-100 \mu \mathrm{g} / \mathrm{mL}$ FLU. Finally, $5 \mu \mathrm{L}$ aliquots of $C$. albicans was sub-cultured into 8 wells $\left(\mathrm{OD}_{600}\right.$ of 0.05$)$ to measure cell growth as a function of FLU concentration. The $\mathrm{OD}_{600}$ of cultures was read every 10 mins over a period of $48 \mathrm{~h}$ at $37^{\circ} \mathrm{C}$ using a plate reader (Cytation 5 imaging reader, BioTek Instruments Inc.). The growth curves were analyzed in the $\mathrm{R}$ Studio using the package Growthcurver ${ }^{41}$ Each curve was fit to a logarithmic equation, and the area under the curve was integrated and compared for statistical difference. The minimal reference concentration with significant inhibitory effects on the growth of $C$. albicans was used to study the synergy between the drug and the low-level electrochemical DCs.

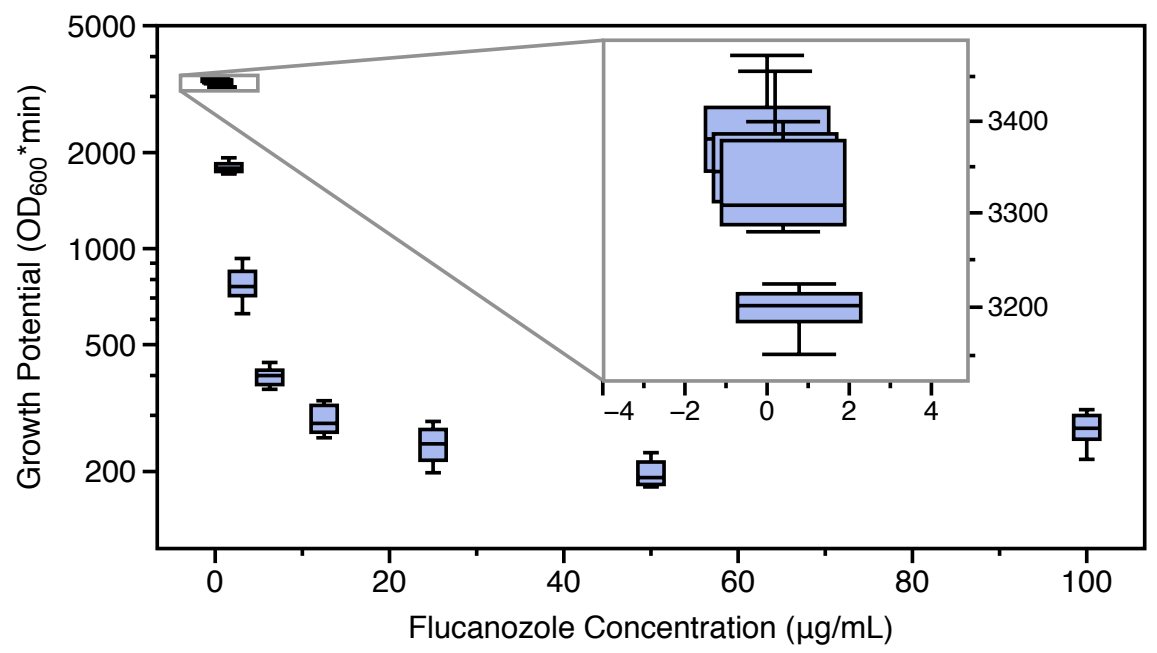

Fig. S8. Growth potential of $C$. albicans in UFTYE in the presence and absence of fluconazole. Planktonic cells were exposed to $0.2-100 \mu \mathrm{g} / \mathrm{mL} F L U$ to determine their growth inhibition responses. The absorbance $\left(O D_{600}\right)$ - being directly proportional to the live cell density—was read for each well on a 96-well plate at 10 
min intervals over $48 \mathrm{~h}$ at $37^{\circ} \mathrm{C}$. A total of eight replicates was tested for each of the 12 conditions. The area under the growth curve was calculated and plotted against the drug concentration.

C. albicans was grown in the presence or absence of FLU to record the growth potential of the cells and identify drug concentrations that significantly reduce their metabolic activity and specific growth rate. We have diluted the FLU concentration from 100 to $0 \mu \mathrm{g} / \mathrm{mL}$ adjacently across the rows on the 96-well plate and have collected the $\mathrm{OD}_{600}$ readings at 10-minute time intervals for $48 \mathrm{~h}$ to understand the cell response to FLU exposure. Our results display two trends for the effects of FLU on C. albicans: a sharp decrease and a steady state of the growth potentials. FLU concentrations ranging between $1.5-3 \mu \mathrm{g} / \mathrm{mL}$ did reduce the specific growth potential of C. albicans by $50 \%$, and a $95 \%$ reduction was achieved with $12.5 \mu \mathrm{g} / \mathrm{mL}$ FLU. Additionally, no further reduction of the growth potential was recorded with higher $(12.5$ to $100 \mu \mathrm{g} / \mathrm{mL}$ ) FLU concentration (Fig. S5). The growth potential remained steady between 200 and $300 \mathrm{OD}_{600}{ }^{*} \min$. Interestingly, concentrations of 5 and $12.5 \mu \mathrm{g} / \mathrm{mL}$ (reducing the growth potential by $50 \%$ and $95 \%$, respectively) were tested on $C$. albicans in their stationary phase, and they did not prove to cause significant reduction of the cell viability (Fig. S5, $p=0.89$ ). The $C$ albicans cells were not killed at all with 5 and 12.5 $\mu \mathrm{g} / \mathrm{mL}$ FLU, suggesting that the stationary phase cells exhibited higher FLU tolerance.

\section{Synergy between the electrochemical and fluconazole treatments}

The electrochemical treatments were conducted concurrently in the presence of $5 \mu \mathrm{g} / \mathrm{mL}$ and $12.5 \mu \mathrm{g} / \mathrm{mL}$ FLU to understand if DC low-levels have any synergy with FLU. We aimed to confirm the hypothesis that the electrochemical treatments could alter some metabolic functions in C. albicans and enhance the killing efficacy of antifungal drugs that were previously found ineffective against the stationary phase cells. The cells were then treated with a range of DC levels varying between $17.5 \mu \mathrm{A} / \mathrm{cm}^{2}$ and $70 \mu \mathrm{A} / \mathrm{cm}^{2} \mathrm{DC}$ with 5 or $12.5 \mu \mathrm{g} / \mathrm{mL}$ FLU concentrations simultaneously. By comparing all the treatment with $5 \mu \mathrm{g} / \mathrm{mL}$ FLU, a time dependent killing (two-way ANOVA, $p=0.03$ ) was found. However, there was no significant difference between the treatment conditions. The concurrent treatments did not seem to improve the killing activity of the current densities. 


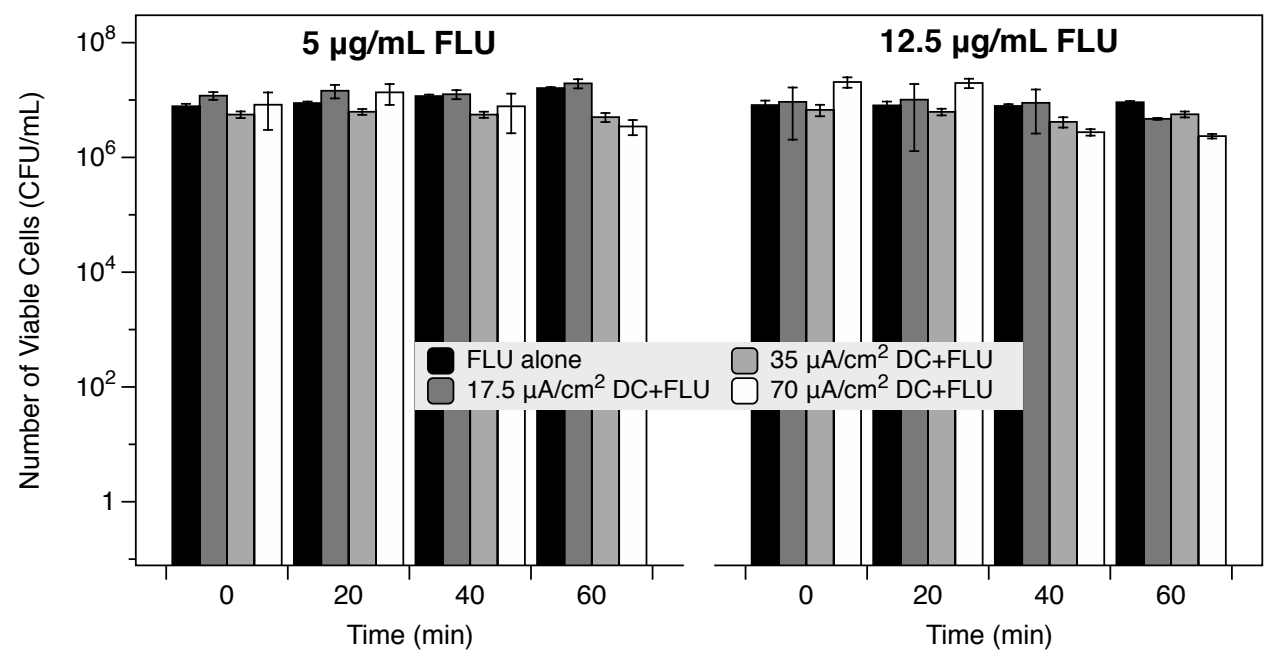

Fig. S9. Effects of DC treatment with FLU on planktonic C. albicans cells. No synergy was found when the cells were treated with DC that was generated using $70 \mathrm{uA} / \mathrm{cm}^{2} \mathrm{DC}$ and 5 or $12.5 \mathrm{ug} / \mathrm{mL}$ FLU simultaneously.

\section{References}

(1) Bard, A. Standard Potentials in Aqueous Solution. Routledge: 2017.

(2) Kiamco, M. M.; Zmuda, H. M.; Mohamed, A.; Call, D. R.; Raval, Y. S.; Patel, R.; Beyenal, H. Hypochlorous-Acid-Generating Electrochemical Scaffold for Treatment of Wound Biofilms. Sci. Rep. 2019, 9 (1), 2683.

(3) Hadacek, F.; Greger, H. Testing of Antifungal Natural Products: Methodologies, Comparability of Results and Assay Choice. Phytochem. Anal. 2000, 11 (3), 137-147.

(4) Sprouffske, K.; Wagner, A. Growthcurver: An R Package for Obtaining Interpretable Metrics from Microbial Growth Curves. BMC bioinformatics 2016, 17 (1), 172. 